\title{
Balance Control in Obese Subjects during Quiet Stance: A State-of-the Art
}

\author{
Veronica Cimolin ${ }^{1, * \mathbb{D}}$, Nicola Cau ${ }^{2}$, Manuela Galli ${ }^{1} \mathbb{D}$ and Paolo Capodaglio ${ }^{2}$ \\ 1 Department of Electronics, Information and Bioengineering (DEIB) Politecnico di Milano; Piazza Leonardo \\ da Vinci 32, 20133 Milano, Italy; manuela.galli@polimi.it \\ 2 Ospedale San Giuseppe, Istituto Auxologico Italiano, IRCCS, Strada Luigi Cadorna 90, 28824 \\ Piancavallo (VB), Italy; nicola.cau@gmail.com (N.C.); p.capodaglio@auxologico.it (P.C.) \\ * Correspondence: veronica.cimolin@polimi.it
}

Received: 3 February 2020; Accepted: 4 March 2020; Published: 7 March 2020

check for updates

\begin{abstract}
Obese individuals are characterized by a reduced balance which has a significant effect on a variety of daily and occupational tasks. The presence of excessive adipose tissue and weight gain could increase the risk of falls; for this reason, obese individuals are at greater risk of falls than normal weight subjects in the presence of postural stress and disturbances. The quality of balance control could be measured with different methods and generally in clinics its integrity is generally assessed using platform stabilometry. The aim of this narrative review is to present an overview on the state of art on balance control in obese individuals during quiet stance. A summary of knowledge about static postural control in obese individuals and its limitations is important clinically, as it could give indications and suggestions to improve and personalize the development of specific clinical programs.
\end{abstract}

Keywords: posture; stability; force platform; stabilometry; posturography; obesity

\section{Introduction}

Postural stability can be explained as the ability of one's motor control to maintain the standing posture, even during external perturbations. It is often described as static (quiet standing) or dynamic (maintaining a stable position while undertake a prescribed movement) [1].

Postural stability is achieved when a subject can regain equilibrium after being disturbed. Postural control requires the integration of inputs from various sensory systems, which are: (a) the proprioceptive system (receptors in joints, muscles, tendons, skin) [2], (b) the visual system [3] and (c) the vestibular system (semicircular canals and macular otoliths) [4]. Sensorimotor integration and balance regulation rely on the cerebellum; most of the evidence of the function of the cerebellum in humans comes from patients with cerebellar damage who display balance abnormalities and gait ataxia [5].

This multimodal (integrating visual, vestibular, and proprioceptive inputs) and redundant control causes chaotic center of mass (CoM) oscillations known as postural sway [6-8]. In clinics the quality and integrity of balance control is generally assessed using various measures of postural sway [6].

Instrumental evaluation with platform stabilometry or static posturography is a technique where CoM fluctuations are represented by the center of foot pressure (CoP) displacements [9] and it consists in the measurement of forces exerted against a force platform during quiet stance. This method is widely used in clinical settings to evaluate the integrity of the postural control system and to obtain functional markers on fine competencies and their development in different testing conditions (i.e., eyes open vs. eyes closed, feet position, and presence of external stimuli) [10]. Commonly, the study of properties of the CoP trajectory in clinics is performed using traditional time series, in particular analyzing length, displacement excursion, velocity and frequency analysis. The main advantages of these analysis techniques are the simplicity of the experimental set-ups and the safety for the subjects evaluated, a 
particularly important consideration in pathological conditions [11]. However, some limitations are present: (a) the lack of a normal pattern due to intra- and inter-individuals variability; (b) the difficulties inherent to standardizing the measurement experimental set-up (reproducibility of the experimental protocol, environmental conditions, random errors, signal processing); and (c) the presence of highly coupled parameters measured by means of the force platform $[12,13]$. Due to the presence of these limitations, it is necessary to have reliable methods available to extract physiologically significant information from the platform data [11,14]. Alongside the study of properties of the CoP trajectory using traditional time series, some advanced mathematical methods have been developed applying a dynamic approach, such as entropy and fractal dimension (FD) analysis $[11,15,16]$. Even if previous studies $[14,17,18]$ suggested that these methods could represent reliable techniques complementary to the analysis in time and frequency domain in order to evaluate postural control, their use in clinical setting is not yet widespread.

Balance is a fundamental element in carrying out daily life activities. Aging and various pathologies increase the postural instability which can lead to falls [19]. In particular, some anthropometric measurements (height and weight) are demonstrated to significantly influence both postural sway and postural stability $[12,20,21]$. The excessive presence of fat adds mass to different regions and modifies the body geometry [22]: in this way the altered CoM position leads to balance impairments [23].

It is estimated that in 2016, more than 1.9 billion adults aged 18 years and older were overweight; of these over 650 million were obese [24]. A recent paper suggests that by 2030 nearly one in two adults in the United States will be obese and nearly one in four adults will have severe obesity [25]. Patients with obesity have intrinsically reduced postural stability and balance as compared with their normal-weight counterparts. This reduced stability increases linearly with body mass index (BMI). They are at increased risk of falling at any age [26]. Although many studies investigated the risk of falling in obese individuals, balance exercises in these individuals are often not implemented in the rehabilitation program. After implementing a rehabilitation program with specific balance exercises, patients with obese have shown to improve their balance control. Maffiuletti et al. [19] showed that just 4-min of specific balance training incorporated into the physical exercise routine improved postural stability in patients with severe obesity. The recommended exercise program for patient with obesity is a multicomponent 90-min exercise program that includes 15-min balance training, 15-min flexibility, 30-min aerobic exercise and 30-min high-intensity resistance training [27]. Different aspects of balance control can be addressed:

1. Treatment of biomechanical constraints (weakness, reduced range of motion, reduced flexibility, and improper postural alignment).

2. Weight shifting exercise to treat reduced limits of stability.

3. Sensory retraining of balance control.

4. Training of anticipatory postural adjustments focused on improving postural preparation for transition from one position to another (sit-to-stand single-leg-stance, step initiation, and compensatory forward stepping).

5. Training postural responses to perturbations.

6. Dynamic stability during gait (i.e., walking in different directions and environments).

The consensus is that obese individuals exhibit poor postural stability $[28,29]$; the aim of this review will be to present an overview on the state of art on balance control in obese individuals during quiet stance. A summary of our current knowledge about static postural control in obese individuals is important from a clinical perspective, as it could allow for the development of clinical programs that are more oriented towards the needs of this population, even avoiding the risk of comorbidity due to falls. 


\section{Methods}

We conducted an extensive search of the relevant literature, with a focus on studies/articles published in the last 15 years (2004-2019). The literature search was performed in November 2019 on the following electronic databases: Web of Science, PubMed MEDLINE, Scopus, and Mendeley. Customized queries including keywords and Boolean logic with AND/OR operators were entered in this form: "(balance OR posture OR stability) AND (posturography) AND (obesity)", with document type set to "Article". The search was limited to full original articles written in English. Bibliographies of identified papers were hand searched for supplemental relevant items.

All included studies had to meet the following criteria: overweight and obese adults (18-75 years; with body mass index $\left.(\mathrm{BMI}) \geq 25 \mathrm{Kg} / \mathrm{m}^{2}\right)$; studies assessing obese patients with genetic obesity; evaluations performed with force platform. We excluded studies that were not primarily focused on the evaluation of quiet standing evaluation (dynamic balance) in obese subjects, or non-adult participants and elderly subjects.

\section{Results}

A total of 27 records were retrieved from the electronic databases. Eight items were added by visual inspection of reference lists and review articles. After removing seven duplicates, titles and abstracts screening led to exclude four papers. Out of the remaining 24 articles, 12 failed to meet inclusion criteria. The main reasons for exclusion were as follows: studies assessing elderly or non-adult patients; patients with neuropathy; the presence of other pathologies (multiple sclerosis). The selection process is summarised in Figure 1.

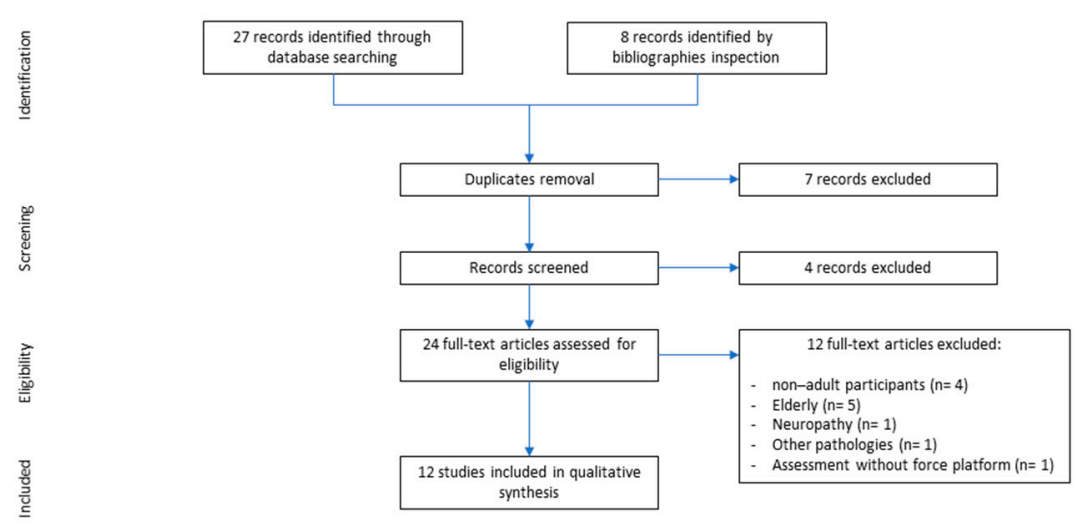

Figure 1. Diagram of study selection.

Table 1 presents a summary of the papers on postural ability in obese individuals with the demographic characteristics of the evaluated individuals and some details of the experimental set-up (trial duration, conditions, feet position, analyzed parameters). 
Table 1. Summary of the main details of the reviewed studies.

\begin{tabular}{|c|c|c|c|c|c|c|c|c|c|}
\hline Source & Year & Country & $\begin{array}{l}\text { \# Participants and } \\
\text { Gender (\# M/F) }\end{array}$ & Age (Yrs.) & $\begin{array}{l}\text { BMI }\left(\mathrm{Kg} / \mathrm{m}^{2}\right) \text { (the } \\
\text { Weight }(\mathrm{kg}) \text { Is } \\
\text { Reported When BMI } \\
\text { Is Not Present) }\end{array}$ & Parameters & $\begin{array}{c}\text { Trial } \\
\text { Duration }\end{array}$ & Conditions & Foot Position \\
\hline Hue et al. [30] & 2007 & Canada & Total: $59(\mathrm{M})$ & $40.5 \pm 9.5$ & $35.2 \pm 11.7$ & $\begin{array}{l}\text { CoP RMS (AP and ML) } \\
\text { CoP Range (AP and } \\
\text { ML) Sway area Mean } \\
\text { CoP velocity (AP and } \\
\text { ML) RMS of CoP } \\
\text { velocity }\end{array}$ & $\begin{array}{c}35 \mathrm{~s} \text { (last } 30 \mathrm{~s} \\
\text { used for the } \\
\text { analysis) }\end{array}$ & $\begin{array}{l}\text { Eyes open/eyes } \\
\text { closed }\end{array}$ & Feet $10 \mathrm{~cm}$ apart \\
\hline Teasdale et al. [31] & 2007 & Canada & $\begin{array}{l}\text { Total: } 44 \text { (M) } \\
\text { Divided into } \\
\text { Control group: } 16 \\
\text { Obese group: } 14 \\
\text { Morbid group: } 14\end{array}$ & $\begin{array}{l}\text { Control group: } \\
38.6 \pm 9.4 \\
\text { Obese group: } \\
37.9 \pm 7.7 \\
\text { Morbid group: } \\
44.4 \pm 8.9\end{array}$ & $\begin{array}{c}\text { Control group: } \\
22.7 \pm 2.2 \text { Obese group: } \\
33 \pm 3 \text { Morbid group: } \\
50.5 \pm 6.8\end{array}$ & $\begin{array}{l}\text { CoP RMS (AP and ML) } \\
\text { CoP Range (AP and } \\
\text { ML) Mean CoP velocity } \\
\text { (AP and ML)RMS of } \\
\text { CoP velocity }\end{array}$ & $\begin{array}{c}35 \mathrm{~s} \text { (last } 30 \mathrm{~s} \\
\text { used for the } \\
\text { analysis) }\end{array}$ & $\begin{array}{l}\text { Eyes open/Eyes } \\
\text { closed }\end{array}$ & Feet together \\
\hline Menegoni et al. [32] & 2009 & Italy & $\begin{array}{c}\text { Total: } 44 \\
\text { M: 22/F: } 22\end{array}$ & $19-58$ & $\begin{array}{l}\mathrm{M}: 41.1 \pm 4.1 \\
\mathrm{~F}: 40.2 \pm 5\end{array}$ & $\begin{array}{l}\text { CoP RMS (AP and ML) } \\
\text { CoP Range (AP and } \\
\text { ML) Mean CoP velocity } \\
\text { (AP and ML) }\end{array}$ & $60 \mathrm{~s}$ & Eyes open & $\begin{array}{c}\text { Standardised } \\
\text { (distance between } \\
\text { heels approx. } 8 \mathrm{~cm} \\
\text { and angle between } \\
\text { feet of } 30^{\circ} \text { ) }\end{array}$ \\
\hline Blaszczyk et al. [33] & 2009 & Poland & Total. $100(\mathrm{~F})$ & $18-53$ & $37.2 \pm 5.2$ & $\begin{array}{c}\text { CoP range (AP and } \mathrm{ML}) \\
\text { CoP length } \\
\text { CoP Range (AP and }\end{array}$ & $30 \mathrm{~s}$ & $\begin{array}{l}\text { Eyes open/eyes } \\
\text { closed }\end{array}$ & $\begin{array}{c}\text { Feet apart and } \\
\text { slightly turned out }\end{array}$ \\
\hline Cimolin et al. [17] & 2011 & Italy & $\begin{array}{c}\text { Total: } 11 \text { (PWS) M: } \\
\text { 5/F: } 6\end{array}$ & $34.4 \pm 3.7$ & $41.4 \pm 8.1$ & $\begin{array}{c}\text { ML) CoP length peak of } \\
\text { the spectrum (AP and } \\
\text { ML) FD }\end{array}$ & $30 \mathrm{~s}$ & Eyes open & Feet at a $30^{\circ}$ angle \\
\hline $\begin{array}{c}\text { Cruz-Gomez et al. } \\
{[34]}\end{array}$ & 2011 & Mexico & $\begin{array}{l}\text { Total: } 180 \text { M: 90/F: } \\
\text { 90 Divided into } \\
\text { Lean (\%): M: 41; F: } \\
\text { 37 Overweight (\%): } \\
\text { M: 48; F: } 33 \text { Obese } \\
\text { (\%): M: } 11 ; \text { F: } 30\end{array}$ & $\begin{array}{c}12-67 \\
\text { (M:34.9 } \pm 12.27 \\
\text { F:36.76 } \\
\text { (12.02) }\end{array}$ & $\begin{array}{c}\mathrm{M}: 25.97 \pm 3.73 \\
\mathrm{~F}: 26.83 \pm 4.77\end{array}$ & $\begin{array}{c}\mathrm{CoP} \text { length } \mathrm{CoP} \text { area } \\
\mathrm{CoP} \text { velocity }\end{array}$ & $25.6 \mathrm{~s}$ & $\begin{array}{l}\text { 1. Hard surface and } \\
\text { eyes open. } 2 \text {. Hard } \\
\text { surface and eyes } \\
\text { closed. } 3 \text {. Soft } \\
\text { surface and eyes } \\
\text { open. } 4 \text {. Soft } \\
\text { surface and eyes } \\
\text { closed }\end{array}$ & $\begin{array}{l}\text { According to the } \\
\text { manufacturer } \\
\text { reference }\end{array}$ \\
\hline Rigoldi et al. [35] & 2011 & Italy & $\begin{array}{l}\text { Total: } 45 \text { (DS) } \\
\text { (gender not } \\
\text { detailed) }\end{array}$ & $22-46$ & $57.9+10.8 \mathrm{Kg}$ & $\begin{array}{c}\text { CoP Range (AP and } \\
\text { ML) CoP length peak of } \\
\text { the spectrum (AP and } \\
\text { ML) }\end{array}$ & $30 \mathrm{~s}$ & $\begin{array}{l}\text { Eyes open/eyes } \\
\text { closed }\end{array}$ & Feet at a $30^{\circ}$ angle \\
\hline
\end{tabular}


Table 1. Cont

\begin{tabular}{|c|c|c|c|c|c|c|c|c|c|}
\hline Source & Year & Country & $\begin{array}{l}\text { \# Participants and } \\
\text { Gender (\# M/F) }\end{array}$ & Age (Yrs.) & $\begin{array}{l}\text { BMI }\left(\mathrm{Kg} / \mathrm{m}^{2}\right) \text { (the } \\
\text { Weight }(\mathrm{kg}) \text { Is } \\
\text { Reported When BMI } \\
\text { Is Not Present) }\end{array}$ & Parameters & $\begin{array}{c}\text { Trial } \\
\text { Duration }\end{array}$ & Conditions & Foot Position \\
\hline $\begin{array}{l}\text { Hita-Contreras et al. } \\
\text { [36] }\end{array}$ & 2013 & Spain & Total: $100(\mathrm{~F})$ & $57.51 \pm 3.99$ & $27.10 \pm 4.71$ & $\begin{array}{l}\text { CoP RMS (AP and ML) } \\
\text { Sway area Mean CoP } \\
\text { velocity (AP and ML) }\end{array}$ & $30 \mathrm{~s}$ & $\begin{array}{l}\text { 1. Eyes open } 2 . \\
\text { Eyes closed } 3 \text {. Foam } \\
\text { surface and eyes } \\
\text { open } 4 \text {. Foam } \\
\text { surface and eyes } \\
\text { closed }\end{array}$ & Feet at a $30^{\circ}$ angle \\
\hline Cimolin et al. [37] & 2014 & Italy & $\begin{array}{l}\text { Total } 59 \text { M: 15; F: } 11 \\
\text { M: 6; F: } 7 \text { (PWS) M: } \\
\text { 11; F: } 9 \text { (DS) }\end{array}$ & $\begin{array}{c}34.2 \pm 10.7 \\
32.4 \pm 4.2 \\
(\mathrm{PWS}) \\
29.1 \pm 8.1(\mathrm{DS})\end{array}$ & $\begin{array}{c}40.6 \pm 4.640 .3 \pm 6.6 \\
\text { (PWS) } 35.8 \pm 6.2 \text { (DS) }\end{array}$ & $\begin{array}{l}\text { CoP Range (AP and } \\
\text { ML) CoP length peak of } \\
\text { the spectrum (AP and } \\
\text { ML) FD }\end{array}$ & $30 \mathrm{~s}$ & Eyes open & Feet at a $30^{\circ}$ angle \\
\hline $\begin{array}{c}\text { Cieslinska-Swider et al. } \\
\text { [38] }\end{array}$ & 2017 & Poland & $\begin{array}{c}\text { Total: } 80 \text { (F) } \\
\text { Divided into Group } \\
\text { A: } 40 \text { with android } \\
\text { type of obesity } \\
\text { Group G: } 40 \text { with } \\
\text { gynoid type of } \\
\text { obesity }\end{array}$ & $\begin{array}{c}\text { Group A: } \\
38 \pm 12 \text { Group } \\
\text { G: } 36 \pm 11\end{array}$ & $\begin{array}{l}\text { Group A: } 37.6 \pm 5.5 \\
\text { Group G: } 36.9 \pm 5.1\end{array}$ & $\begin{array}{l}\mathrm{CoP} \text { range (AP and } \mathrm{ML}) \\
\mathrm{CoP} \text { mean velocity } \mathrm{CoP} \\
\text { peak velocity }\end{array}$ & $30 \mathrm{~s}$ & $\begin{array}{l}\text { Eyes open/eyes } \\
\text { closed }\end{array}$ & $\begin{array}{c}\text { Feet apart and } \\
\text { slightly turned out }\end{array}$ \\
\hline Hirjakova et al. [39] & 2018 & Slovakia & Total: 22 M: 13/F: 9 & $32.5 \pm 1.3$ & $32.0 \pm 0.9$ & $\begin{array}{l}\text { CoP Range (AP and } \\
\text { ML) Mean CoP velocity } \\
\text { (AP and ML) }\end{array}$ & $50 \mathrm{~s}$ & Eyes open & $\begin{array}{l}\text { Self-selected stance } \\
\text { width }\end{array}$ \\
\hline $\begin{array}{l}\text { Cieslinska-Swider et al. } \\
\text { [8] }\end{array}$ & 2019 & Poland & Total: $32(\mathrm{~F})$ & $35.9 \pm 9.8$ & $36.4 \pm 5.2$ & $\begin{array}{c}\mathrm{CoP} \text { range (AP and } \mathrm{ML}) \\
\mathrm{CoP} \text { mean velocity } \mathrm{CoP} \\
\text { peak velocity }\end{array}$ & $30 \mathrm{~s}$ & $\begin{array}{l}\text { Eyes open/eyes } \\
\text { closed }\end{array}$ & $\begin{array}{c}\text { Feet apart and } \\
\text { slightly turned out }\end{array}$ \\
\hline
\end{tabular}

Abbreviations: M: male; F: female; PWS: Prader-Willi syndrome; DS: Down syndrome; BMI: body mass index; ROM: range Of motion; AP: antero-posterior; ML: medio-lateral; FD:

fractal dimension. 


\subsection{Study Population}

The sample size of participants ranged from $n=11$ to $n=180$ (mean age range: 19 years to 60 years). A total of 860 subjects were involved (approximately $60 \%$ females and $40 \%$ males), but we could not exclude subjects overlapping in studies conducted by the same research group.

\section{Experimental Set-up and Parameters}

In terms of the experimental set-up, the common postural techniques are used in terms of trial duration ( $30 \mathrm{~s}$ or $60 \mathrm{~s}$ ) and conditions (eyes open and eyes closed). On the contrary, some differences were found as for the feet position; this could represent a bias as it is demonstrated that anthropometric measurements (e.g., maximum foot width), and the foot position could influence balance [12]. Almost all the studies have been conducted using parameters obtained by time-domain analysis of the CoP trajectory (length, displacement excursion, velocity).

To the best of our knowledge, most studies in obese individuals have adopted the traditional time-domain approach. However, a growing number of studies have been designed to explore other approaches for the analysis of the CoP trajectories during quiet standing and to characterize the preferential involvement of specific neuronal loops in postural regulation (frequency), its irregularity and complexity (entropy), its chaotic pattern (fractal dimension method), etc. [40].

Nevertheless, these alternative methodologies have not been used in obese patients. To our knowledge, only few researches $[17,37]$ quantified posture using the FD approaches in addition to the time and frequency domain in genetic obese patients (Prader-Willi syndrome and Down syndrome). The results showed that patients presented higher CoP fluctuations in both AP and ML directions with longer CoP trajectory than the control group [35,41-43] and similar values as for the frequency analysis. Furthermore, the pathological individuals presented larger excursions of $\mathrm{CoP}$ with the same velocity of oscillation if compared to normal weight individuals. In addition, patients with genetic obesity exhibited higher FD values, which were higher in patients with Down syndrome. According to these results, the time domain parameters do not seem to clearly highlight early anomalies in postural maintenance: the traditional method does not investigate the chaotic fluctuations of CoP trajectories. Frequency analysis and dynamical system theory could identify early changes and may match time frequency analysis to assess balance. However, the clinical interpretation of the results is not completely clear and requires further in-depth investigation.

\subsection{Gender Effects}

Gender differences (considering in particular gynoid and android shape) are observed in terms of body mass distribution, even if android fat distribution is also found in females, especially in postmenopausal women: nevertheless, the research for possible gender-specific differences in balance has reported contradictory findings. Some studies were conducted just on a specific gender (males or females).

\subsubsection{Males}

Hue et al. [30] observed that obese men presented higher instability, in both the antero-posterior (AP) and medio-lateral (ML) CoP excursions, than normal weight individuals; an improvement was found in severely obese men after weight loss [31] and specific balance training [19]. This result supports the suggestion that body weight is an important predictor of postural stability [30].

\subsubsection{Females}

Blaszczyk et al. [33] observed a significant postural instability in all obese patients; CoP fluctuations were higher in patients with the highest body mass index $\left(>40 \mathrm{~kg} / \mathrm{m}^{2}\right)$. In another study, Cienliska-Swider et al. [38] quantified CoP characteristics in a group of obese women with android type of obesity as compared with a group of obese women with gynoid type of obesity, standing 
with eyes open and closed. They found that women with abdominal obesity showed a larger sway range in the AP direction under both conditions and a greater maximal CoP velocity than subjects with gynoidal obese type under the eyes closed condition. Women with abdominal obesity seem to exhibit greater postural instability in comparison with women with gynoid fat distribution. In another study conducted by the same authors [8] on young obese women, they found that participants exhibited sagittal plane postural instability only with their eyes closed. After body weight reduction, ML static stability decreased, directly connected to a change in the base of support. Recently, Hita-Contreras [36] analyzed the relationship between body weight/body fat distribution and postural balance and their correlation with falls in postmenopausal women, which are characterized by weight gain and increased central adiposity. In the obese group, higher excursions were found in the antero-posterior direction under both eyes-open and eyes-closed conditions, as well as for the CoP velocity. In particular, in overweight and obese individuals with an android body fat distribution a good correlation with the risk of falling was found. Similar results were found in obese older women, suggesting that obesity has a negative impact on the capacity of older woman to adequately use proprioceptive information for posture control [44].

\subsubsection{Males vs. Females}

If instability was generally observed both in obese males and female, it is not clear whether gender could influence balance. Cruz-Gomez et al. [34] assessed the influence of BMI group (lean/overweight/obese) and gender on the postural sway of adolescents and adults during quiet upright stance in four conditions (eyes open/closed on hard/soft surface). The postural stability of obese subjects decreases with eyes closed, if compared to normal weight individuals, with no influence of the gender. Thus, they found no interactions between the BMI group and the gender, independently of the age of the subjects. On the contrary, in another study, Menegoni et al. [32] identified a gender-specific effect in obese individuals: both genders displayed instability in AP direction, while only males presented ML destabilization. The difference in male and female body tissue distribution could potentially offer two related explanations to these outcomes. While males typically store more fatty tissue around their abdomen, (android shape), females usually carry fat around the hips and the upper portion of their legs (gynoid shape) [45]. AP instability is exacerbated in both populations by greater overall mass which leads to higher ankle torque. The male distribution of mass, however, results in increased loading of the pelvic girdle which, in turn may contribute to greater ML CoP excursion. Similar, yet alternatively, the anatomically lower position of fat storage associated with the female gynoid shape has a consequently lower CoM than the male android shape.

\subsection{General Considerations}

In general, body weight is considered a predictor of postural instability [30], from adolescence onwards [26]. In obese individuals there is significantly greater forward CoP displacement during dynamic standing balance activities [46]. Excessive body weight affects posture linearly with the increase of BMI $(0.39<$ rho $<0.60, p<0.05)$ [47,48], similarly to the later stages of pregnancy [31], the center of gravity shifts forward, lumbar lordosis increases together with the pelvic forward tilt, dorsal kyphosis and secondary cervical lordosis become more pronounced [49]. Otherwise, increased CoP parameter values and therefore increased postural instability during quiet stance has been reported in both morbidly and slightly obese subjects [39]. Two hypotheses have been proposed to explain the presence of higher oscillations in obese individuals in comparison with normal weight subjects: a) the reduction of plantar sensitivity due to the hyper activation of the plantar mechanoreceptors for the continuous pressure of supporting the large mass; $b$ ) the presence of high mechanical request in obese subjects due to a whole body center of mass further away from the axis of rotation causing a greater gravitational torque [30]. 


\section{Conclusions}

According to this narrative review, the research investigating the effect of adiposity on postural balance is limited and, to date, has primarily focused on parameters related to time-domain approach during bipedal stance.

Because of the elevated mass to height ratio of excessively muscular people, BMI becomes a relatively ineffective method for differentiating between highly overweight subjects and bulky, yet fit, muscular subjects. This could be a potential explanation for the discrepancies found in studies using BMI as their sole classification metric. The relationship between excessive adiposity and balance may be better explained using different measures of fat percentage. Rather, by including the ratio of circumference between waist and hip, researchers could add a quantitative parameter (in addition to the traditional BMI) which characterizes the shape of a subject and subsequently ensure better homogeneity amongst groups.

Considering that the prevalence of obesity is increasing at a rapid rate all over the world, health systems will have to face the growing problems directly related to obesity. It is now known that an increase in BMI is associated with an increase in functional limitation, decreased stability and an increased risk of falls. Complications associated with falls are often more difficult to treat in obese individuals in comparison with normal-weight subjects. Targeted physical activity and rehabilitation would seem to lead to improvements in terms of balance in obese people; it is still unclear whether a regular exercise program and weight loss could be the first steps in countering the reduced balance related to obesity. Balance exercises are often neglected in rehabilitation programs; evidence exists that majority of patients with obesity complain of dizziness, but they seem to underestimate the risk of fall; considering the increased risk of fall, balance exercises for the patient with obesity should be implemented even in the absence of specific balance disorders.

The main limitation of this review is mainly related to the age of the evaluated patients. A more extensive review could be conducted evaluating also the effects of age (elderly) and non-adult participant's (children and adolescents). In addition, it could be interesting to consider dynamic balance training in these patients, which has been proven improving balance performance and decreases falls in these subjects.

Author Contributions: V.C. contributed to conceptualization, Writing—original draft, Writing-review \& editing; N.C. Data curation, Formal analysis, Writing-original draft; M.G. contributed to conceptualization, Supervision, Writing - review \& editing; P.C. Project administration, Supervision, Writing-review \& editing. All authors have read and agreed to the published version of the manuscript.

Funding: This research received no external funding.

Conflicts of Interest: The authors declare no conflict of interest.

\section{References}

1. Karimi, M.T.; Solomonidis, S. The relationship between parameters of static and dynamic stability tests. J. Res. Med. Sci. Off. J. Isfahan Univ. Med. Sci. 2011, 16, 530-535.

2. Maranesi, E.; Fioretti, S.; Ghetti, G.G.; Rabini, R.A.; Burattini, L.; Mercante, O.; Di Nardo, F. The surface electromyographic evaluation of the Functional Reach in elderly subjects. J. Electromyogr. Kinesiol. 2016, 26, 102-110. [CrossRef]

3. Alghadir, A.H.; Alotaibi, A.Z.; Iqbal, Z.A. Postural stability in people with visual impairment. Brain Behav. 2019, 9, e01436. [CrossRef] [PubMed]

4. Appiah-Kubi, K.; Wright, W. Vestibular training promotes adaptation of multisensory integration in postural control. Gait Posture 2019, 73, 215-220. [CrossRef] [PubMed]

5. Yanagihara, D. Role of the cerebellum in postural control. J. Phys. Fit. Sports Med. 2014, 3, 169-172. [CrossRef]

6. Błaszczyk, J.W. The use of force-plate posturography in the assessment of postural instability. Gait Posture 2016, 44, 1-6. [CrossRef] [PubMed]

7. Maurer, C.; Peterka, R.J. A New Interpretation of Spontaneous Sway Measures Based on a Simple Model of Human Postural Control. J. Neurophysiol. 2005, 93, 189-200. [CrossRef] [PubMed] 
8. Cieślińska-Świder, J.M.; Błaszczyk, J.W. Posturographic characteristics of the standing posture and the effects of the treatment of obesity on obese young women. PLOS ONE 2019, 14, e0220962. [CrossRef]

9. Winter, D. Human balance and posture control during standing and walking. Gait Posture 1995, 3, $193-214$. [CrossRef]

10. Maranesi, E.; Merlo, A.; Fioretti, S.; Zemp, D.D.; Campanini, I.; Quadri, P. A statistical approach to discriminate between non-fallers, rare fallers and frequent fallers in older adults based on posturographic data. Clin. Biomech. 2016, 32, 8-13. [CrossRef]

11. Sabatini, A.M. Analysis of postural sway using entropy measures of signal complexity. Med. Biol. Eng. Comput. 2000, 38, 617-624. [CrossRef] [PubMed]

12. Chiari, L.; Rocchi, L.; Cappello, A. Stabilometric parameters are affected by anthropometry and foot placement. Clin. Biomech. 2002, 17, 666-677. [CrossRef]

13. Kim, Y.; Morshed, S.; Joseph, T.; Bozic, K.; Ries, M.D. Clinical Impact of Obesity on Stability Following Revision Total Hip Arthroplasty. Clin. Orthop. 2006, 453, 142-146. [CrossRef] [PubMed]

14. Capodaglio, P.; Menegoni, F.; Vismara, L.; Cimolin, V.; Grugni, G.; Galli, M. Characterisation of balance capacity in Prader-Willi patients. Res. Dev. Disabil. 2011, 32, 81-86. [CrossRef]

15. Doyle, T.L.; Newton, R.U.; Burnett, A.F. Reliability of Traditional and Fractal Dimension Measures of Quiet Stance Center of Pressure in Young, Healthy People. Arch. Phys. Med. Rehabil. 2005, 86, 2034-2040. [CrossRef]

16. Galli, M.; Rigoldi, C.; Celletti, C.; Mainardi, L.; Tenore, N.; Albertini, G.; Camerota, F. Postural analysis in time and frequency domains in patients with Ehlers-Danlos syndrome. Res. Dev. Disabil. 2011, 32, 322-325. [CrossRef]

17. Cimolin, V.; Galli, M.; Rigoldi, C.; Grugni, G.; Vismara, L.; Mainardi, L.; Capodaglio, P. Fractal dimension approach in postural control of subjects with Prader-Willi Syndrome. J. NeuroEngineering Rehabil. 2011, 8, 45. [CrossRef]

18. Goldberger, A.L.; Amaral, L.A.N.; Hausdorff, J.M.; Ivanov, P.C.; Peng, C.-K.; Stanley, H.E. Fractal dynamics in physiology: Alterations with disease and aging. Proc. Natl. Acad. Sci. USA 2002, 99, 2466-2472. [CrossRef]

19. Maffiuletti, N.A.; Agosti, F.; Proietti, M.; Riva, D.; Resnik, M.; Lafortuna, C.L.; Sartorio, A. Postural instability of extremely obese individuals improves after a body weight reduction program entailing specific balance training. J. Endocrinol. Invest. 2005, 28, 2-7. [CrossRef]

20. Alonso, A.C.; Mochizuki, L.; Silva Luna, N.M.; Ayama, S.; Canonica, A.C.; Greve, J.M.D.A. Relation between the Sensory and Anthropometric Variables in the Quiet Standing Postural Control: Is the Inverted Pendulum Important for the Static Balance Control? BioMed Res. Int. 2015, 2015, 1-5. [CrossRef]

21. Cau, N.; Cimolin, V.; Galli, M.; Precilios, H.; Tacchini, E.; Santovito, C.; Capodaglio, P. Center of pressure displacements during gait initiation in individuals with obesity. J. NeuroEngineering Rehabil. 2014, 11, 82. [CrossRef] [PubMed]

22. de Souza, S.A.F.; Faintuch, J.; Valezi, A.C.; Sant' Anna, A.F.; Gama-Rodrigues, J.J.; de Batista Fonseca, I.C.; Souza, R.B.; Senhorini, R.C. Gait Cinematic Analysis in Morbidly Obese Patients. Obes. Surg. 2005, 15, 1238-1242. [CrossRef] [PubMed]

23. Li, X.; Aruin, A.S. The effect of short-term changes in body mass distribution on feed-forward postural control. J. Electromyogr. Kinesiol. 2009, 19, 931-941. [CrossRef]

24. World Health Organisation Obesity and overweigth. Available online: https://www.who.int/news-room/factsheets/detail/obesity-and-overweight(accessed on 6 March 2020).

25. Ward, Z.J.; Bleich, S.N.; Cradock, A.L.; Barrett, J.L.; Giles, C.M.; Flax, C.; Long, M.W.; Gortmaker, S.L. Projected U.S. State-Level Prevalence of Adult Obesity and Severe Obesity. N. Engl. J. Med. 2019, 381, 2440-2450. [CrossRef]

26. McGraw, B.; McClenaghan, B.A.; Williams, H.G.; Dickerson, J.; Ward, D.S. Gait and postural stability in obese and nonobese prepubertal boys. Arch. Phys. Med. Rehabil. 2000, 81, 484-489. [CrossRef] [PubMed]

27. Mathus-Vliegen, E.M.H.; Basdevant, A.; Finer, N.; Hainer, V.; Hauner, H.; Micic, D.; Maislos, M.; Roman, G.; Schutz, Y.; Tsigos, C.; et al. Prevalence, Pathophysiology, Health Consequences and Treatment Options of Obesity in the Elderly: A Guideline. Obes. Facts 2012, 5, 460-483. [CrossRef]

28. Menegoni, F.; Milano, E.; Trotti, C.; Galli, M.; Bigoni, M.; Baudo, S.; Mauro, A. Quantitative evaluation of functional limitation of upper limb movements in subjects affected by ataxia. Eur. J. Neurol. 2009, 16, $232-239$. [CrossRef] 
29. Son, S.M. Influence of Obesity on Postural Stability in Young Adults. Osong Public Health Res. Perspect. 2016, 7, 378-381. [CrossRef]

30. Hue, O.; Simoneau, M.; Marcotte, J.; Berrigan, F.; Doré, J.; Marceau, P.; Marceau, S.; Tremblay, A.; Teasdale, N. Body weight is a strong predictor of postural stability. Gait Posture 2007, 26, 32-38. [CrossRef]

31. Teasdale, N.; Hue, O.; Marcotte, J.; Berrigan, F.; Simoneau, M.; Doré, J.; Marceau, P.; Marceau, S.; Tremblay, A. Reducing weight increases postural stability in obese and morbid obese men. Int. J. Obes. 2007, 31, 153-160. [CrossRef]

32. Menegoni, F.; Galli, M.; Tacchini, E.; Vismara, L.; Cavigioli, M.; Capodaglio, P. Gender-specific Effect of Obesity on Balance. Obesity 2009, 17, 1951-1956. [CrossRef] [PubMed]

33. Błaszczyk, J.W.; Cieślinska-Świder, J.; Plewa, M.; Zahorska-Markiewicz, B.; Markiewicz, A. Effects of excessive body weight on postural control. J. Biomech. 2009, 42, 1295-1300. [CrossRef] [PubMed]

34. Cruz-Gómez, N.S.; Plascencia, G.; Villanueva-Padrón, L.A.; Jáuregui-Renaud, K. Influence of Obesity and Gender on the Postural Stability during Upright Stance. Obes. Facts 2011, 4, 212-217. [CrossRef] [PubMed]

35. Rigoldi, C.; Galli, M.; Mainardi, L.; Crivellini, M.; Albertini, G. Postural control in children, teenagers and adults with Down syndrome. Res. Dev. Disabil. 2011, 32, 170-175. [CrossRef]

36. Hita-Contreras, F.; Martínez-Amat, A.; Lomas-Vega, R.; Álvarez, P.; Mendoza, N.; Romero-Franco, N.; Aránega, A. Relationship of body mass index and body fat distribution with postural balance and risk of falls in Spanish postmenopausal women. Menopause 2013, 20, 202-208. [CrossRef]

37. Cimolin, V.; Galli, M.; Rigoldi, C.; Grugni, G.; Vismara, L.; de Souza, S.A.F.; Mainardi, L.; Albertini, G.; Capodaglio, P. The fractal dimension approach in posture: a comparison between Down and Prader-Willi syndrome patients. Comput. Methods Biomech. Biomed. Engin. 2014, 17, 1535-1541. [CrossRef]

38. Cieślińska-Świder, J.; Furmanek, M.P.; Błaszczyk, J.W. The influence of adipose tissue location on postural control. J. Biomech. 2017, 60, 162-169. [CrossRef]

39. Hirjaková, Z.; Šuttová, K.; Kimijanová, J.; Bzdúšková, D.; Hlavačka, F. Postural Changes During Quiet Stance and Gait Initiation in Slightly Obese Adults. Physiol. Res. 2018, 985-992. [CrossRef]

40. Paillard, T.; Noé, F. Techniques and Methods for Testing the Postural Function in Healthy and Pathological Subjects. BioMed Res. Int. 2015, 2015, 1-15. [CrossRef]

41. Cimolin, V.; Galli, M.; Grugni, G.; Vismara, L.; Precilios, H.; Albertini, G.; Rigoldi, C.; Capodaglio, P. Postural strategies in Prader-Willi and Down syndrome patients. Res. Dev. Disabil. 2011, 32, 669-673. [CrossRef]

42. Galli, M.; Rigoldi, C.; Mainardi, L.; Tenore, N.; Onorati, P.; Albertini, G. Postural control in patients with Down syndrome. Disabil. Rehabil. 2008, 30, 1274-1278. [CrossRef] [PubMed]

43. Galli, M.; Cimolin, V.; Vismara, L.; Grugni, G.; Camerota, F.; Celletti, C.; Albertini, G.; Rigoldi, C.; Capodaglio, P. The effects of muscle hypotonia and weakness on balance: A study on Prader-Willi and Ehlers-Danlos syndrome patients. Res. Dev. Disabil. 2011, 32, 1117-1121. [CrossRef] [PubMed]

44. Dutil, M.; Handrigan, G.A.; Corbeil, P.; Cantin, V.; Simoneau, M.; Teasdale, N.; Hue, O. The impact of obesity on balance control in community-dwelling older women. AGE 2013, 35, 883-890. [CrossRef] [PubMed]

45. Clark, C.C.T.; Barnes, C.M.; Holton, M.; Summers, H.D.; Stratton, G. Profiling movement quality and gait characteristics according to body-mass index in children (9-11 y). Hum. Mov. Sci. 2016, 49, 291-300. [CrossRef] [PubMed]

46. Berrigan, F.; Simoneau, M.; Tremblay, A.; Hue, O.; Teasdale, N. Influence of obesity on accurate and rapid arm movement performed from a standing posture. Int. J. Obes. 2006, 30, 1750-1757. [CrossRef] [PubMed]

47. Gilleard, W.; Smith, T. Effect of obesity on posture and hip joint moments during a standing task, and trunk forward flexion motion. Int. J. Obes. 2007, 31, 267-271. [CrossRef]

48. Corbeil, P.; Simoneau, M.; Rancourt, D.; Tremblay, A.; Teasdale, N. Increased risk for falling associated with obesity: mathematical modeling of postural control. IEEE Trans. Neural Syst. Rehabil. Eng. 2001, 9, 126-136. [CrossRef]

49. Rodacki, A.L.F.; Fowler, N.E.; Provensi, C.L.G.; Rodacki, C.D.L.N.; Dezan, V.H. Body mass as a factor in stature change. Clin. Biomech. 2005, 20,799-805. [CrossRef]

(C) 2020 by the authors. Licensee MDPI, Basel, Switzerland. This article is an open access article distributed under the terms and conditions of the Creative Commons Attribution (CC BY) license (http://creativecommons.org/licenses/by/4.0/). 